Reconciling Contemporary Gifted Education with Its Foundations

\author{
Jennifer L. Jolly \\ University of Alabama \\ Russell T. Warne \\ Utah Valley University
}




\begin{abstract}
Gifted education in the 21 st century is in a state of tension regarding its past. Many early pioneers of the field held scientific and social views that are out of step with modern theory in gifted education. Yet, many of these people's work is foundational to gifted education practice in the 21 st century schools. Viewpoints of how to navigate this past while maintaining allegiance to modern theory include disowning that past, ignoring it, and building upon it. In this paper, we explore (a) the emergence of gifted education as a field, (b) the early history of gifted education and how it impacts the field today, and (c) suggestions for navigating the tension between the past and the present in gifted education. Though gifted education is over one hundred years old, its early history is still relevant and provides theoretical and practical insights in the form of groundbreaking research, theoretical insights, and cautionary tales.
\end{abstract}

Key words: gifted education, intelligence testing, history of education, eugenics, psychology 


\section{Reconciling Contemporary Gifted Education with Its Foundations}

Many areas of applied psychology are the result of scientific attempts to solve a social problem. Drawing on the successes of the applied physical and biological sciences in addressing the concerns of society, applied psychology has the goal of using scientific methods and knowledge about human psychology to better manage social problems, reduce the frequency of unfavorable social outcomes for people, and improve the functioning of individuals. Some areas of applied psychology have seen great success in achieving practitioners' social goals, such as the use of applied behavior analysis, which is an outgrowth of behaviorist psychology. Other fields have been less successful, such as social psychology, which has experienced numerous failed replication attempts in recent years (e.g., Camerer et al., 2018; Open Science Collaboration, 2015), which calls into question whether subtle changes to people's environment can effectively alter human behavior.

Gifted education is a field of applied psychology that—like other applied areas—is the product of applying scientific theories, knowledge, and methods to real-world problems. Unlike many areas of psychology, though, education is, by definition, a social enterprise that happens at the individual and group levels. As such, gifted education is bound up within societal contexts and concerns in a way that some other applied psychology fields are not. Consequently, the research, findings, and advances in theory of gifted education cannot be divorced from the social context that they are in some other fields of applied psychology. As society moves away from context in which the original research was conducted, the value of research rooted in past ideals and concerns may come under scrutiny. Yet, science is a cumulative enterprise, and it is not always feasible to distance, in this case, the applied psychology practice of gifted education from 
earlier ideas because current practices will have some grounding in past knowledge — and therefore past contexts. This creates a tension when later generations have ethical and moral standards that are at odds with that scholarly past. Our goal in this paper is to explore that tension by (a) explaining the social and scientific context that gave birth to gifted education approximately 100 years ago, (b) giving brief summaries of early gifted education pioneers and discuss their enduring influence, (c) exploring the consequences for modern gifted education framed within this foundational period, and (d) providing suggestions to gifted education scholars and practitioners for how this tension might be balanced, even if a resolution cannot be completely achieved.

\section{Gifted Education's Beginnings}

Although "gifted," "bright," or "precocious" children have always existed, gifted education as a field of practice and scholarly inquiry is a relatively recent innovation in industrial societies. For most of human history, a child's education was individualized, such as apprenticeships, working with a parent in order to learn a trade, or mentoring with an experienced co-worker. Under such conditions, gifted education is unnecessary because a gifted student is a learner who masters new information and skills unusually rapidly and/or thoroughly, and their strong learning ability is easily accommodated in the individualized setting (Jolly, 2018). Even in a one-room schoolhouse setting, the needs of gifted learners were more easily addressed because they could advance through the curriculum at their own pace; less able students often dropped out of school, as few accommodations were made for their learning needs, leaving only capable students attending school in the upper grades (Gaither, 2017).

What occurred in the early 20th century to make a field like gifted education a possibility? In short, several societal, educational, and scientific changes occurred in the late 19th 
and early 20th centuries to create a perceived need among administrators and scholars for scientifically-based practices to accommodate academically advanced learners. These changes transformed the education system in the United States into a large-scale enterprise that worked well if children's academic abilities were similar. But when children performed consistently better than their peers, the inadequacy of this new educational regime became apparent. To accommodate these children, it was necessary to develop new research, theories, and practice- $\mathrm{a}$ need that provided a fertile environment for gifted education to evolve.

Progressive education reform in the late 19th and early 20th century also played an important role in cultivating an environment that allowed the interventionist strategies of gifted education to find a foothold. This time period presented American schools and school systems with a set of challenges that had not been previously encountered before. These challenges included an expanding student population, not only in size but diversity, skyrocketing operating costs, and changing curricular demands (Berube, 1994; Chapman, 1988). Running parallel to the challenges of American schools, psychology—based in scientific objectivity—emerged as a force with the potential for solving these educational problems (Lagemann, 2000). Psychological researchers in increasing numbers identified ways in which to apply the principles and practices of this burgeoning field could disentangle the ever more complicated American school (Cremin, 1964; Jolly, 2018; Zimmerman \& Schunk, 2009). The purpose of schooling also experienced a transference. Rather than bounds set by content and criteria, influential psychologists such as G. Stanley Hall, advocated for a child-centered approach to teaching and educational opportunities for those in attendance (Cremin, 1964).

Compulsory schooling and the enactment of laws banning child labor enabled a large number of children to move off farms and out of factories into formalized schooling for the first 
time in America's history, with many compulsory schooling and child labor laws passed by the end of the 19th century (Richardson, 1980; Tyack, 1976). A gradual understanding of the link between economic success and education also began to emerge, providing an even stronger rationale to remove children from the often dangerous and low paying jobs in which they were employed and into formalized education (Mayer, 2013).

The massive European migration that occurred from 1881 to 1920 brought 23.5 million immigrants to the United States (U.S. Citizenship and Immigration Service, 2012), and quickly the children in these communities began to populate public schools. Within this time period, two distinct geographic groups from Europe would migrate to the United States. The initial group of immigrants largely came from Ireland, England, and Germany. The second wave of migrants, from Southern and Eastern Europe, chose to settle in urban centers. The latter group had an immediate impact on schools as they introduced new languages and cultures to schools. These differences were further exacerbated when in 1917 the requirement to be able to read and write in one's native language was removed. Low literacy levels in some migrant homes further diminished the English language resources available to children (Martin \& Duigan, 2003; U.S. Citizen and Immigration Service, 2012).

Public schools, particularly in cities and metropolitan areas, experienced historical growth in enrollments. In addition to teaching reading, writing, and arithmetic, schools were also expected to help immigrant children understand their role in American society (Fass, 1980). Intersecting with this milieu, American farming families increasingly began their own migration to urban centers, filling the assembly line jobs and openings in factories_-also impacting school enrollments. In 1860, approximately 4 million children attended public schools across the United States. Four decades later, in 1900 that number nearly tripled to 11 million children. In 1920, 
approximately 18.5 million children attended public schools, with the greatest concentration of students found in city centers (NCES, 1993). Educating sizable groups of children was not unheard of in the United States. What was different was the diversity in native language, socioeconomic status, cultural background, and/or academic ability. Tools and strategies would be required to address a range of challenges that now faced many of American schools for the first time (Chapman, 1988).

Concurrent with societal changes, scientific advances in the late 1800s and early 1900s occurred that made formal scholarly investigation of gifted children possible. The first important scientific advance is the correlation coefficient (Pearson, 1896). The correlation coefficient is now one of the most common statistical procedures in the social sciences (Skidmore \& Thompson, 2010; Warne, Lazo, Ramos, \& Ritter, 2012), so the correlation's revolutionary nature may not be obvious to the modern scientist. With the invention of Pearson's (1896) correlation coefficient, it was possible to precisely quantify the strength of the relationship between variables and to compare correlations in order to determine which relationships would be stronger or weaker than others. Although Karl Pearson did not invent the idea of association between two variables (see Galton, 1886, for a famous example), the invention of the correlation coefficient greatly expanded the scientific questions that could be posed—and answered—about how variables were related to one another.

The correlation coefficient's implications remain widespread because it allowed scientists to investigate the existence of individual differences of all types (Norton, 1978), and its use soon spread to other fields, including psychology (Bellhouse, 2009). For gifted education, one important consequence was the ability to study individual differences in educational performance and aptitude as an exact, quantitative endeavor. Gifted education is - by definition — a field built 
on individual differences. If individual differences in aptitude, mastery of the curriculum, learning speed, or cognitive abilities cannot be measured, then it is impossible to customize the education of "gifted" children in any systematic way.

The second implication of the correlation coefficient that had an important impact on gifted education is that correlations can be used to make predictions. By using a correlation coefficient and independent variable scores, it is possible to use regression to predict dependent variable scores (Warne, 2018). The ability to predict outcomes was important early in the history of gifted education because prediction can be used to determine whether "giftedness" is enduring - i.e., whether giftedness at one point in life correlated with giftedness later. Finding correlations between variables was also important in establishing whether high ability in a scholastic setting had any relationship with non-academic variables. Until the correlation coefficient was developed these questions either could not be asked, or there were no suitable scientific tools for answering them.

Less than a decade after Pearson developed his correlation coefficient, another scientific development with profound and lasting implications for gifted education was developed. In 1905, France's Binet and Simon (1905/1916) published their intelligence test, which allowed psychologists and education personnel to objectively measure the intelligence level of children. ${ }^{1}$ Binet's test was the culmination of over a decade's study in children's cognitive development (Wolf, 1973) and the work of other scientists (Gibbons \& Warne, 2019). However, what set Binet and Simon's work apart from these earlier efforts was the creation of a single test that could quantify the differences in intelligence among children. Binet revised his test twice more, in 1908 and 1911, just before his sudden death in 1911. These revisions improved the test

\footnotetext{
${ }^{1}$ Binet was not the first to attempt to scientifically measure intelligence; that distinction goes to Sir Francis Galton (Gillham, 2001).
} 
without changing its purpose: to identify children who were struggling in school and needed additional educational supports.

Binet's tests were inadequate for identifying gifted children because the test's ceiling was too low to identify children with high cognitive performance. In the United States, Lewis Terman recognized this problem and realized that to be suitable for identifying gifted children, Binet's test needed to include questions that were challenging enough for bright students. During the 1910's, he adapted the test to an American examinee population and added many questions of increased difficulty (Terman, 1916). The result was a test capable of identify children who were perceived as "gifted."

Though not favored by many gifted education theorists today (e.g., Cross \& Cross, 2017), the creation of intelligence tests was an essential pre-requisite for the development of a science of gifted education. Prior tests were locally developed and administered, with no scientific foundation in their construction (e.g., Hall, 1893). The tests lacked the trappings of scientific objectivity that Binet's test possessed with its foundation in developmental psychology. Moreover, Binet purported that his test measured intelligence, which some scholars believed was an innate psychological property of the examinee (e.g., Dawson, 1930; Young, 1924). This implied that there was a special subpopulation of people who were intrinsically "gifted," identifiable, and worthy of scientific study.

\section{Societal Context}

At the same time that gifted education was emerging, there were a variety of social concerns and developments that would make the education and development of highly intellectually able people relevant. The first was the early 20 th century progressive faith in the expert as a person who could solve problems facing American society. School officials and 
psychologists became "reluctant allies" for answers to the question of how to handle new educational problems, like organizing schools with expanding enrollments and handling heterogeneous classrooms (Chapman, 1988; Lagemann, 2000, p. 23). Psychologists were experts who proposed one cause of these difficulties: hetereogeneity. Special classes for gifted children could address students' differences in intellectual ability. This was seen as a use of psychological expertise to understanding how to organize schools (e.g., Dickson, 1922).

The reason experts were seen as so useful to early 20th century elites was the expert's use of science to solve societal problems. Successful initiatives in public health, economics, and other areas were based on the use of scientific observation, data collection, and experimentation to solve problems. Given the perceived value of applying science to solving societal problems, it was probably inevitable that educational scholars would begin to use scientific methods to solve educational problems. The perceived cachet that science brought to these experts' proposed solutions made them an attractive policy for school personnel. This is why the objective appearance of the intelligence test was an important event in the founding of gifted education: it gave the field an immediate respect that flowed from the elevated status of a science (e.g., Terman, 1922).

The era's faith in the expert and scientific methods were its most lasting, positive contributions to society (in general) and to gifted education (specifically). However, another contemporary culture was much more negative in its effects: eugenics. This was a social movement designed to harness the then-new theories arising from evolutionary theory and to apply this to the wellbeing of the human species.

Although it had earlier antecedents (Kevles, 1995), the modern eugenics movement began in the late 1800s when Sir Francis Galton - the creator of the scatterplot and a relative of 
Charles Darwin — proposed the use of evolutionary principles to improve humanity's fitness and ability to "improve" the species and its chances for survival in the future (Galton, 1883). Galton suggested regulations and incentives to encourage people with desirable traits to have more children, while discouraging people with undesirable traits from having children. He proposed a government scheme where people could have their physical health, intelligence, and other traits independently evaluated; individuals with particularly beneficial traits would receive a certificate of their fitness as a mate. He also suggested financial incentives for people with desirable traits to have large families (Gillham, 2001).

Galton proposed eugenics in response to what he saw as an evolutionary problem: in Great Britain at the time, wealthy, educated families (like Galton's) had fewer children than the uneducated families. Extrapolating several generations into the future, Galton (1883) anticipated a time when the descendants of the lower classes would greatly outnumber the descendants of Galton's social class - perhaps even to the point where the latter would be extinct. Because Galton saw Britain's upper class as the engine for the country's military and economic dominance of the world, this future was dystopian to Galton to the point where this imbalance in descendants could even be a threat to society or the survival of the species (Galton, 1883).

The logic of Galton's eugenics was appealing because of its foundation on evolutionary theory as it was understood at the time. More important, though, was that eugenics validated the prejudices of Galton and other elites (Kevles, 1995; MacKenzie, 1976; Stepan, 1991). Galton believed that people from his social class would have desirable traits, and other educated, wealthy and successful individuals assumed the same. Conversely, the marginalized groups and individuals in society—including racial minorities, the poor, and people with disabilities—were often assumed to be those with undesirable traits who should be discouraged from reproducing. 
Eugenics spread worldwide in the early decades of the 20th century, and in each country it allowed politically and economically powerful people to exert power over others in order to shape society and future generations in a way that the those with influence and power preferred (Kevles, 1995; Stepan, 1991). As eugenics spread, it took on various forms in different countries. In the United Kingdom, it was relatively benign, with almost no eugenics laws passing Parliament and only mild social support for efforts for the upper classes to have more children (Kevles, 1995). Scandinavian countries passed a wide variety of eugenics laws, some of which regulated marriage of people with epilepsy, psychological diagnoses, and disabilities (Broberg \& Roll-Hansen, 2005). Eugenics in the United States had multiple components, including the British tendency to encourage wealthy people to have larger families. However, American eugenics had a sinister undercurrent in the forced sterilization laws that a majority of states passed; these laws precipitated Germany's forced sterilization law in 1933 (Grodin, Miller, \& Kelly, 2018; Stern, 2005). Germany's experience with forced sterilization laid the foundation for involuntary euthanasia in the name of eugenics and later the genocide and concentration camps of the Holocaust (Grodin et al., 2018).

Eugenic policies required someone to judge who had traits that were desirable to be passed on. Inevitably, eugenicists from the educated classes, usually from their nation's dominant ethnic group, appointed themselves to identify which traits would be desirable (Kevles, 1995; MacKenzie, 1976; Stepan, 1991). Many of these judgements were classist and/or racist, and some eugenicists viewed entire groups of people — such as impoverished families, immigrants, criminals, and minorities—as having undesirable traits. As a consequence, these underprivileged and often vulnerable and powerless groups disproportionately experienced the 
negative impacts of eugenic policies (e.g., Broberg \& Roll-Hansen, 2005; Kevles, 1995; Stern, 2005).

\section{Examples from Gifted Education of the Historical Context}

The pioneers of gifted education in the early 20th century were not immune from the scientific and social influences of the time. Some capitalized on the scientific developments of intelligence testing and the correlational coefficient to advance the nascent science of gifted education. And, in keeping with the time, they used their position as experts to attempt to solve educational problems using scientific methods. However, some also embraced eugenic thinking that reached its peak in the United States in the 1920s.

Several key individuals were crucial in the establishment of the field of gifted education. Their work provided a foundational set of directional points for subsequent practitioners and researchers to build upon, interrogate, and refine over the next century. For the purposes of this paper, we discuss Guy M. Whipple, Lulu Stedman, Leta Hollingworth, and Lewis Terman based on their particular and unique contributions at this fundamental point in American education and scientific progress.

Guy M. Whipple, who was a member of the early wave of the first influential psychologists in the opening decades of the 20th century, made his contribution to gifted education in field's embryonic stage. Whipple also gained prominence for his work in psychometrics and measurement, the scientific study of eye-witness testimony, and as editor of a number of influential publications over the course of his career (Bagley, 1942). Whipple, much like his contemporaries, felt that the scientific rigor of the new field of psychology could be applied to solve many societal problems of the new century, which included those impacting American schools (Jolly, 2007). As a member of the World War I Committee on the 
Psychological Examination of Recruits, Whipple actively developed the practical application of intelligence tests and their role in sorting recruits during basic training and played a significant role in developing the new field of measurement. He also authored one of the first influential texts devoted to this topic, Manual of Mental and Physical Tests (1910).

Predating the launch of Terman's longitudinal study by several years, Whipple began his own study of bright children by applying his expertise in mental measurement (specifically intelligence tests) to identify high-IQ children. He hypothesized that children who scored well above the average required specialized curricula to develop this potential indicated by testing (Whipple, 1922). The label "gifted" cast upon these children with advanced mental ability can be attributed to Whipple. As Henry noted, "we owe the term 'gifted' as the standard designation of children of supernormal ability" to Whipple (1920, p. 9) and remains his most enduring contribution to the field. During the 1916-1917 school year, Whipple used available mental measures and applied the subsequent results in a classroom setting. These results appeared in Classes for Gifted Children (Whipple, 1919), one of the first systematic pieces of research employing mental measures and using these results to construct appropriate educational experiences. Still, Whipple's primary goal was to determine the capabilities of these new mental measures to identify "gifted" children. The educational interventions were a secondary point of inquiry. This initial work also posed questions regarding teacher qualifications, pupil selection, courses and curricula, and pedagogy (Whipple, 1919).

Though Whipple's foremost interest lay in understanding the strengths and limitations of measures such as the intelligence test, his approach to identifying and educating gifted children combined the two ideological camps of thought prevalent during Progressive Education movement (1890-1930) of the early 20th century. Pedagogical progressives' and administrative 
progressives' approach to educational reform diverged significantly. Pedagogical progressives focused on the learning needs and learning experiences of children, while administrative progressives looked to tools such as IQ tests allowing of the sorting and grouping of students to bring about transformational learning environments (Chapman, 1988; Labaree, 2005).

Lulu Stedman is a lesser-known figure in gifted education, however, her contributions included the first curricular understandings of matching curriculum and pedagogy to gifted children's advanced abilities. Lulu Stedman was a clinical professor in education who taught at the Los Angeles State Normal School's (the current day University of California, Los Angeles), lab school (Jolly, 2006). There she crossed paths with a number of children who did not cope well with the normal curriculum because of their advanced abilities. One particular student enrolled in the lab school convinced Stedman that some radical changes were required to accommodate individual differences in academic performance. At the same time the Normal School was transitioning to become part of the University of California system, Stedman established the opportunity rooms in the university's lab school aimed at better providing for the educational needs of gifted students based on IQ scores of 120 and above (Stedman, 1924).

William T. Root of the University of Pittsburgh collaborated with Stedman to develop the companion social and psychological studies to support the practical work she undertook in the opportunity room (Root, 1921). Based on this work, Stedman developed 19 recommendations, some of which mirrored the earlier work that Whipple had conducted. Some of these 19 that are still found in gifted education best practice today include an endorsement of acceleration through the curriculum, independent study, development of creative endeavors, and time to concentrate on existing special abilities or deficits (Stedman, 1924). The results and findings from her opportunity room served as the basis for the work that Leta Hollingworth undertook in her own 
opportunity rooms at P.S. 165 and P.S. 500 (Hollingworth, 1926). Lewis Terman's brief tenure at the Normal School overlapped with Stedman's, and he would eventually serve as editor of her book Education of Gifted Children (1924). Virtually nothing is known about Stedman's personal life, and the work she did after the publication of Education of Gifted Children. Yet her contributions are integral to the earliest formal curricular provisions for gifted children, even as they remain a footnote and underappreciated in terms of their impact and influence on the larger field of gifted education (Jolly, 2006).

Leta S. Hollingworth, often referred to as the mother of gifted education, built upon the initial findings of Whipple and Stedman. Unlike Stedman, who focused on the practical implementation of best practices in the classroom for gifted children, and Whipple, who was decidedly more interested in the practical application and usefulness of the IQ test to identify gifted children, Hollingworth combined the practice and science of education using psychological principles to adjust curriculum and pedagogy (Jolly, 2018). Her husband, Harry Hollingworth, was also a noted psychologist, and his pursuit of a Ph.D. at Columbia University brought the Hollingworths to New York City. Leta would eventually earn her Ph.D. under E. L. Thorndike at the Teachers College (Benjamin, 2013).

Raised in what could only be described as disadvantaged household with few material resources and often abusive stepmother, Leta was encouraged to extend her education by a high school teacher who recognized her intellectual potential. The earliest part of the 20th century offered few career paths for women and Leta pursued teaching at the University of Nebraska. This is also where she met her husband (H. L. Hollingworth, 1990). After securing a faculty positing at Teachers College, Hollingworth had a chance interaction with a gifted young child, called Child E (and now known publicly to be Edward Rochie Hardy, Jr.; see Wigtil \& White, 
2017), who was brought into her course as a demonstration subject for an intelligence test. His extraordinary performance provided her with an impetus to what would be the cornerstone of building a sustained field of study of gifted education (L. S. Hollingworth, 1922).

From 1923 to 1925, Hollingworth would have the opportunity to develop an educational program for students who demonstrated above average IQs through the then-new intelligence tests at P.S. 165, a New York Public School that often worked in collaboration with Teachers College (L. S. Hollingworth, 1924a). It was here that Hollingworth operationalized her hypotheses about advanced ability children's need for an alternate type of approach to education, rather than the rote memorization that was particularly fashionable at the time. As the original concept of giftedness was largely built around a pre-determined IQ with cutoff score (typically between 130 and 140), Hollingworth was the first to suggest that qualitative variations existed among children who scored above a cutoff score and that different types of curricular approaches would be required to meet their needs (L. S. Hollingworth, 1924b). She instituted both advancement and enrichment of the curriculum, suggesting that too much acceleration could put a child in an awkward social situation with which they would not be able to cope. The findings from P.S. 165 were culled and included in Gifted Children: Their Nature and Nurture, which was published in 1926 and is considered to be the first textbook in the field of gifted education. In addition to the curricular interventions, Hollingworth began the data collection for her longitudinal study of the students who enrolled at P.S. 165. This collection in some form would continue until her untimely death in 1939 (H. L. Hollingworth, 1990; Jolly, 2018).

P.S. 165 originally a two-year commitment, left an array of questions that were only partially resolved in Hollingworth's estimation. In 1936, P.S. 500 would be presented with an opportunity to implement new findings from the field and redress issues or provide curricular 
improvements from P.S. 165. The staff at P.S. 500 would also make a concerted effort to recruit children that reflected the diverse population of the Lower East side of Manhattan (L. S. Hollingworth, 1936a, 1936b). Hollingworth also developed a distinctive set of curriculum units, The Evolution of Common Things, to be implemented with students at P.S. 500. These units covered a number of topics with an emphasis on a child's contribution to society (L. S. Hollingworth, 1938). Research on academic acceleration was still developing during this period, and Hollingworth's observations led her to restrict students under her supervision from entering high school before the age of 13 (L. S. Hollingworth 1936b). This recommendation is no longer substantiated by the research literature (Assouline, Colangelo, VanTassel-Baska, \& LupkowskiShoplik, 2015). P.S. 500 students were also recognized for their leadership abilities and the potential gifted students held in this area and Hollingworth published some of the first literature on this topic (L. S. Hollingworth, 1939). Her premature death in 1939, followed by the United States entrance into World War II in 1941, led to the significant curtailment of these areas of research.

While Leta Hollingworth was beginning her studies of gifted children in New York City, Lewis Terman had initiated his own study on the West Coast in California, undertaking an ambitious longitudinal study of 1,528 children. Terman, originally from Indiana and raised in a large farming family, had migrated to California upon graduation from Clark University to seek a better climate for his bouts with tuberculosis (Terman, 1930). He settled as a high school principal in southern California and then went on to finally securing the type of faculty position he always desired at Stanford University in 1910 (Winker \& Jolly, 2014). Interested in academically advanced children since his Ph.D. studies at Clark and heavily influenced by G. Stanley Hall, the president of Clark University during Terman's graduate studies, he began in 
earnest at Stanford to study this particular population. Stanford provided the resources both in time and materials, while also allowing Terman to develop his adaptation of Binet's test, the Stanford-Binet (Jolly, 2018). Along with Whipple, Terman also was a member of the World War I Committee on the Psychological Examination of Recruits and was heavily influenced by the potential uses of intelligence tests and other mental measures to solve societal issues, including those existing in schools (Chapman, 1988).

The 1916 Stanford-Binet was one of several measures used during the data collection of the subjects in Terman's longitudinal study, aiding in its predominance in the emerging intelligence test market. Terman unequivocally believed in its ability to measure what it was intended to measure while also recognizing its limitations. This longitudinal study also amassed the first data on gifted children outside of school, providing a snapshot of gifted children's families (Terman, 1925). What this data did not include were those children from certain ethnicities who were absent or severely underrepresented in the sample, including African American, Italian, Portuguese, Japanese, Mexican, and Chinese children, despite their presence in California's schools. The study's sample also underscored Terman's social views of intelligence (Stoskopf, 2002). What initially was to be a 10-year longitudinal study, data continued to be collected on these children for over 7 decades. The study's findings are published over five volumes and provided lines of inquiry into how giftedness revealed itself as child matured into adulthood.

\section{Consequences for Today: Lingering Controversies in Gifted Education}

Educational research, like all social endeavors, has its roots in the past. Even though all the founding figures of gifted education passed away decades ago and the American progressive era ended long ago, the consequences of gifted education's past and the context of its founding 
are still felt today. These initial constructions have been shaped, discarded, and/or nuanced as the field's understandings of psychological science, curricular needs, and societal values have changed.

The early decades of the 20th century in America witnessed the widespread of adoption of eugenic principles and policies in scientific communities and among the general public. The eugenics movement was an arm of the Progressive Era agenda that implemented scientific strategies to manage society through social efficiency (Selden, 2000). By the 1920s, 400 courses in American universities also included eugenics content in their curriculum (Cravens, 1978; Selden, 2005).

Lewis Terman's and Leta Hollingworth's inclusion of eugenic principles in their research agendas is clear. Terman encountered Galton's ideas and theories early in his graduate school work. These would influence his beliefs about influence of heredity on intelligence. California, Terman's home for the majority of his adulthood after graduate school, also pursued a particularly aggressive eugenics agenda (Stern, 2005), while the president of Stanford University (1891-1913), David Starr Jordan, was the first chairman of the Committee on Eugenics of the American Breeders Association. This association set out to identify methods of improving "the family, the people, or the race" through study of heredity (as cited in Selden, 1999, p. 1). Terman also held memberships in various eugenics organizations throughout the 1920s.

Similar to Terman, Hollingworth encountered Galton's writings during her graduate studies and credited his body work as a foundational for her studies of gifted children (L. S. Hollingworth, 1942). Leta Hollingworth, although not an active member in eugenic organizations, did write about eugenic principles and the responsibility parents of gifted children had to society. She noted that society needed more gifted children and urged parents of gifted 
children to have more children, and she was concerned that the parents of gifted children typically chose to have only one or two children (L. S. Hollingworth, 1929).

The 1930s observed a noticeable decline in support of eugenic supporters and activities, as those in the United States attempted to distance themselves from the policies employed by leadership in Nazi Germany and the increasing opposition from the American Catholic Church (Leonard, 2005). Terman and Hollingworth's eugenic dispositions also curtailed with the onset of the 1930s (Rudnitski, 1996). Since the 1930s, untangling the use of intelligence tests as an instrument to further the eugenics movement and also as a tool for gifted education has been difficult.

Partially because this history cannot be changed, practitioners and scholars in gifted education have an unease with intelligence research and intelligence tests. An example of this is seen in the definition of who is gifted and who is not. Only four states include the word "intelligence" in their legal definitions of giftedness; most instead use euphemisms for the term, such as "intellectual ability," or "general intellectual aptitude" (National Association of Gifted Children, 2013). These terms often lack scientific exactness. Moreover, the exact meaning of giftedness changes from jurisdiction to jurisdiction (Borland, 2003; Ford, 1995) As a result, gifted education research often is grounded in vague operationalizations and terminology that shifts from study to study (Dai, Swanson, \& Cheng, 2011), which impedes the formation of a cumulative body of knowledge.

The field's unease with the concept of intelligence contributes to the isolation of gifted education from other scholarly fields (Ambrose, VanTassel-Baska, Coleman, \& Cross, 2010; Robinson, 2006). Gifted education researchers tend to cluster their citations in articles published within gifted education journals and often do not engage with developments in other areas (Jolly 
\& Kettler, 2008; Ritchie, 2013; Vockell \& Conard, 1992). Conversely, intelligence is a multidimensional field with connections to many branches of psychology, human biology, sociology, medicine, and many other areas (Warne, 2016). The isolation of gifted education creates problems when the field uses techniques based on theories from other disciplines without ensuring that they coherently fit with gifted education practice. For example, the widespread use of aptitude tests to identify students for gifted programs is often haphazard because of a lack of understanding of the psychometric and psychological theories that underpin these tests. This results in the tests being used in contradictory ways or in a manner that may undermine practitioners' goals.

The lack of engagement with the intelligence literature has prevented gifted education scholars from information that could shed light on issues that concern them. A prime example of this is the disproportionate representation of racial/ethnic groups that is often found in gifted programs in the United States. Typically, African American students are most underrepresented in gifted programs, compared to the general student population, followed by Hispanic students. Conversely, White students are often overrepresented, and Asian American students are most overrepresented in gifted programs. This is a demographic pattern that extends back at least 40 years, and probably longer (Peters, Gentry, Whiting, \& McBee, 2019). Similarly, intelligence researchers have noticed that people of East Asian descent tend to have the highest average score on intelligence tests, followed—in order—by White examinees, Hispanics, and African Americans (Gottfredson, 1997; Jensen, 1998; Nisbett et al., 2012). The same pattern is also found in average scores on academic achievement tests (e.g., Warne, Anderson, \& Johnson, 2013). This consistent finding across three correlated academic or cognitive variables is probably not a coincidence (Warne, 2016), and it is plausible that the Asian-White-Hispanic-African 
American ordering in gifted programs research, measures of academic achievement, and intelligence tests scores has a common cause. If this is true, then the causes of disproportionate identification in gifted programs is the same — or correlated with — the causes of the achievement gap and mean IQ differences. However, few gifted education researchers seem interested in engaging with these other areas of literature. Instead, they propose remedies for disproportionate representation that are only based on the gifted education literature, such as using nonverbal tests to identify children for gifted programs (e.g., Naglieri, 2007), or improving educators' cultural competence (e.g., Ford, 2014). While these suggestions may have merit, they will be, at best, partially effective because they are not based on the important insights into the causes of group differences that appear in the non-gifted education literature (e.g., Lubke, Dolan, Kelderman, \& Mellenbergh, 2003; Morgan, Farkas, Hillemeier, \& Maczuga, 2016).

Another consequence of gifted education's aversion towards its past is the field's perennial efforts to redefine giftedness since the 1970s. Today, there are a variety of definitions that are policy-driven (National Association for Gifted Children, 2013), developmental (e.g., Morelock, 1992), a mix of cognitive and non-cognitive traits (Renzulli, 1978), or based on developed abilities (e.g., McBee, McCoach, Peters, \& Matthews, 2012). The differences among these definitions for gifted education can be substantial (McBee \& Makel, 2019). Most definitions of giftedness, though, are not based on psychological traits because of an aversion to the simplistic equating of giftedness with high IQ that dominated the early history of the field. However, instead of jettisoning just IQ, many modern scholars have ignored cognitive traits in general. As a result, modern definitions of giftedness context-specific, vague, or otherwise disassociated from the "gifted" person. 
The definitions within gifted education are often contradictory and scientifically insufficient. Replacing the current aversion towards cognitive traits with an engagement with the psychological literature could resolve some of these contradictions, but it would force some scholars in gifted education to understand how various traits relate to one another. It would also require gifted education scholars to give up some of their grasp over the field in order to allow ideas originating from psychology (and not education) to have space to develop and change gifted education. Some scholars have made efforts to incorporate theories and findings from psychology into their work, and the results are promising in their scope, usefulness, and potential to advance both the theory and practice of gifted education (e.g., Subotnik, Olszewski-Kubilus, \& Worrell, 2011).

\section{Suggestions for Today}

The tension between the past and the present is not unique to gifted education. Humans in every historic era —including today—are flawed, and conflicts between earlier figures' ethics and modern standards are inevitable. The likelihood of a conflict between past and present increases as the time between the two periods grows. With gifted education's foundation occurring over 100 years ago, it would be unsurprising if there were not conflicts between the writings of the field's founders and modern scholars. For example, the field of special education is grappling with the contributions and legacy of Hans Asperger. He was one of the original figures in the study of autism, yet there is significant evidence that Asperger was complicit in the Nazi's euthanasia programs targeting children that were judged "undesirable". His actions have required a reconsideration of the terminology and ideas surrounding Asperger (Baron-Cohen, 2018; Falk, 2019). Taking a cue from other fields that have also dealt with this conflict, we have 
some suggestions for gifted education scholars and practitioners for navigating an unseemly past and its lingering impact on the present.

First, we believe that there is value in critically examining the history of gifted education and related fields, such as special education and psychometrics. The interconnected history of these fields provides insight into the genesis and development of modern practices and theories. Understanding the context in which these emerged can help modern practitioners effectively critique or understand what aspects of earlier ideas are enduring today. For example, the history of intelligence testing shows that originally used to solve the problem of educating children to meet their individual needs in an education system that was growing increasingly standardized (Chapman, 1988; Wolf, 1973). The original goal of tailoring education to a child's abilities is still a core part of special education and gifted education (Robinson, Zigler, \& Gallagher, 2000), and standardized tests may still help meet this goal. Other early uses of tests- to further eugenic purposes, for example - were ancillary and rooted in concerns that are not relevant in the 21 st century and that modern practitioners (correctly) reject because of these ideas' scientifically incorrect and morally repulsive foundations. Understanding the historical context of early intelligence test uses helps modern scholars identify worthwhile contributions of the past and build on those while rejecting incorrect ideas.

Second, we recommend that modern scholars engage study the primary literature and approach secondhand with caution. A prime example of an inaccurate representation of the past is Stephen Jay Gould's The Mismeasure of Man (1981, 1996), which portrays intelligence testing as a racist ideology masquerading as pseudoscience. Specifically, Gould makes Terman obsessed with universal testing in order to “... mark a child for life ..." (Gould, 1996, p. 207) and limit opportunities to people who did not score well on his test and establish an IQ-based aristocracy. 
Gould grossly misrepresented the history of testing (Snyderman \& Herrnstein, 1983; Warne, Burton, Gibbons, \& Melendez, 2019), and later scholarly re-assessments of Terman's work have been much more nuanced (e.g., Jolly, 2008; Milton, 2000; Warne, 2019; Winkler \& Jolly, 2014). However, because Gould's book was massively popular, his opinions still influence scholars' views of testing and the history of gifted education (e.g., Ford, Grantham, \& Whiting, 2008), which inhibits (a) the reconciliation of past and present, and (b) a serious consideration of classical theories and techniques to identify and educate gifted children. Secondhand accounts of history can be useful in condensing and synthesizing information. However, secondary authors are human filters of information, and inevitably their goals and biases influence their interpretation of the historical record. This is also true of our interpretation of gifted education's history, and we recommend readers to study the scholarship of gifted education's pioneers, their archived collections (if available), and other primary resources.

Gifted education has an imperfect history populated by some individuals and institutions that would be considered unsavory and not be tolerated in contemporary academic centers for very valid reasons. However, dismissing certain expanses of a field's history due to its divisiveness, as some have suggested (e.g., Trottman Scott, Ford, \& Davis, 2019), is unproductive. Rather an interrogation and critical examination of the work in question in required. The work of these foundational individuals did not occur in a vacuum and is part of a larger contextual milieu that continues to impact contemporary gifted education and talent development. Historical analysis provides the opportunity to systematically deliberate about transformations over time, an individual's contributions, actions, or an event, and the circumstances and environment in which all of this occurs (Wineburg, 2001). Ignoring the past, 
though, allows its influence to continue uninterrogated and without a public understanding of its meaning.

We also recommend that modern scholars recognize that endorsing one idea from a past figure does not imply endorsement of all ideas from that same person. Most scientists—past and present — believe a mix of correct and incorrect ideas. Each of these should be evaluated independently for how well it conforms to empirical data. Where empirically supported ideas are found, they should be discussed and, if possible, developed into evidence-supported practices. Endorsing, for example, classroom enrichment or full-grade acceleration for gifted students does not imply that one also endorses the eugenic or elitist beliefs of gifted education pioneers who supported these educational practices. Science is a buffet, and each scientist is free to pick and choose individual ideas that they find empirically supported; ideas do not come pre-packaged with one another or served with previous individuals' political or social beliefs attached.

Finally, we recommend that modern scholars avoid the genetic fallacy, which is the tendency to judge the merit of an idea on the basis of its source. Judging an idea on the basis of its source is incorrect because morally repugnant people can propose scientifically correct ideas, and virtuous people can be empirically wrong. For example, Kohlman (2013) called the correlation coefficient an example of "eugenic remnants" in the social sciences because Karl Pearson was a eugenicist, and he developed the statistic to further research into theories of inheritance. While it is true that Pearson was a eugenicist (Bellhouse, 2009) and that the correlation coefficient was developed to further his study of heredity (Stigler, 1986), this does not make the correlation coefficient inappropriate for scholarly use. Subscribing to the genetic fallacy in gifted education would make valuable ideas as grade skipping, curriculum enrichment, and longitudinal studies off limits because advocates of these ideas also happened to endorse 
eugenic ideas (Warne, 2019). The only benefit to banning these tools would be to repress the necessary but uncomfortable discussions about the influence of the past and its presence in modern theory and practice. Reconciling the actions and theories of the past with present viewpoints allows a scholarly field to acknowledge its roots in an accurate but ethical fashion. These discussions also encourage accurate perspectives that also allow for present-day concerns and values to be considered and pave the way for future generations to have the same conversations and arrive at their own methods of reconciling the past with their present.

\section{Conclusion}

The history of gifted education is controversial, and those controversies still concern the field today. Rather than disavow the ugly aspects of that history, we believe that the best option is to study this history and engage with it. Only in this manner will the field of gifted education learn to live with its past. The details of how each individual reconciles the past with present goals will vary, and there is probably no single viewpoint that will satisfy all scholars and practitioners. But ignoring, oversimplifying, or denying the past will not make the past go away, nor will it lessen its influence on the present. These tactics will merely hide the past, thereby making its influence more covert and less transparent. We believe that open, honest engagement with the field's history will help the modern gifted education community understand its history and also empower them to alter the nature and strength of that influence on today's practice. 


\section{References}

Ambrose, D., Van Tassel-Baska, J., Coleman, L. J., \& Cross, T. L. (2010). Unified, insular, firmly policed, or fractured, porous, contested, gifted education? Journal for the Education of the Gifted, 33, 453-478. doi:10.1177/016235321003300402

Assouline, S. G., Colangelo, N., VanTassel-Baska, J., \& Lupkowski-Shoplik, A. (Eds.) (2015). A nation empowered (Vol. 2). Iowa City, IA: The Connie Belin \& Jaqueline N. Blank International Center for Gifted Education and Talent Development

Bagley, W. C. (1942). Guy Montrose Whipple. In N. B. Henry (Ed.), The psychology of learning. The forty-first yearbook of the National Society of Education, Part II (pp. 466469). Chicago, IL: National Society for the Study of Education.

Baron-Cohen, S. (2019). The truth about Hans Asperger's Nazi collusion. Nature. Retrieved from https://www.nature.com/articles/d41586-018-05112-1

Bellhouse, D. R. (2009). Karl Pearson's influence in the United States. International Statistical Review, 77, 51-63. doi:10.1111/j.1751-5823.2009.00066.x

Benjamin, L. T., Jr. (2013). Introduction. In L. T. Benjamin, Jr. \& L. R. Barton (Eds.), From Coca-Cola to chewing gum: The applied psychology of Harry Hollingworth (Vol. 2, pp. ix-xx). Akron, OH: The University of Akron Press.

Berube, M. R. (1994). American school reform: Progressive, equity, and excellence movements: 1883-1993: Westport, CT: Praeger Publishers.

Binet, A., \& Simon, T. (1905/1916). New methods for the diagnosis of the intellectual level of subnormals. E. S. Kite, trans. In A. Binet, \& T. Simon (Eds.). The development of 
intelligence in children (the Binet-Simon scale) (pp. 9-36). Baltimore, MD: Williams \& Wilkins.

Borland, J. H. (2003). The death of gifted education: Gifted education without gifted children. In J. H. Borland (Ed.), Rethinking gifted education (pp. 105-124). New York, NY: Teachers College Press.

Broberg, G., \& Roll-Hansen, N. (Eds.). (2005). Eugenics and the welfare state: Norway, Sweden, Denmark, and Finland. East Lansing, MI: Michigan State University Press.

Camerer, C. F., Dreber, A., Holzmeister, F., Ho, T.-H., Huber, J., Johannesson, M., . . Wu, H. (2018). Evaluating the replicability of social science experiments in Nature and Science between 2010 and 2015. Nature Human Behaviour, 2, 637-644. doi:10.1038/s41562-0180399-z

Chapman, P. D. (1988). School as sorters: Lewis M. Terman, applied psychology, and the intelligence testing movement, 1890-1930. New York, NY: New York University Press.

Cravens, H. (1978). The triumph of evolution: American scientists and the heredity-environment controversy, 1900-1941. Philadelphia, PA: University of Pennsylvania Press.

Cremin, L. A. (1964). The transformation of the school: Progressivism in American education. New York, NY: Vintage Books.

Cross, T. L., \& Cross, J. R. (2017). Challenging an idea whose time has gone. Roeper Review, 39, 191-194. doi:10.1080/02783193.2017.1319000

Cravens, H. (1992). The triumph of evolution: American scientists and the heredity-environment controversy, 1900-1941. Philadelphia, PA: University of Philadelphia Press. 
Dai, D. Y., Swanson, J. A., \& Cheng, H. (2011). State of research on giftedness and gifted education: A survey of empirical studies published during 1998-2010 (April). Gifted Child Quarterly, 55, 126-138. doi:10.1177/0016986210397831

Dawson, S. (1930). Psychological tests in relation to education and vocational guidance. British Journal of Psychology, 21, 39-45. doi:10.1111/j.2044-8295.1930.tb00571.x

Dickson, V. E. (1922). Classification of school children according to mental ability. In L. M. Terman (Ed.), Intelligence tests and school reorganization (pp. 32-52). Yonkers-onHudson, NY: World Book Company.

Falk, D. (2019). Non-complicit: Revisiting Hans Asperger's career in Nazi-era Vienna. Journal of Autism and Development Disorders, doi https://doi.org/10.1007/s10803-019-03981-7

Fass, P. A. (1980). The IQ: A cultural and historical framework. American Journal of Education, $88,431-458$.

Ford, D. Y. (1995). Desegregating gifted education: A need unmet. The Journal of Negro Education, 64, 52-62. doi:10.2307/2967284

Ford, D. Y. (2014). Segregation and the underrepresentation of Blacks and Hispanics in gifted education: Social inequality and deficit paradigms. Roeper Review, 36, 143-154. doi:10.1080/02783193.2014.919563

Ford, D. Y., Grantham, T. C., \& Whiting, G. W. (2008). Culturally and linguistically diverse students in gifted education: Recruitment and retention issues. Exceptional Children, 74, 289-306. doi:10.1177/001440290807400302

Gaither, M. (2017). Homeschool: An American history. New York, NY: Palgrave Macmillan. Galton, F. (1883). Human faculty and its development. London, UK: Macmillan and Co. 
Galton, F. (1886). Regression towards mediocrity in hereditary stature. The Journal of the Anthropological Institute of Great Britain and Ireland, 15, 246-263. doi:10.2307/2841583

Gibbons, A., \& Warne, R. T. (2019). First publication of subtests in the Stanford-Binet 5, WAISIV, WISC-V, and WPPSI-IV. Intelligence, 75, 9-18. doi:10.1016/j.intell.2019.02.005

Gillham, N. W. (2001). A life of Sir Francis Galton: From African exploration to the birth of eugenics. New York, NY: Oxford University Press.

Gottfredson, L. S. (1997). Mainstream science on intelligence: An editorial with 52 signatories, history, and bibliography. Intelligence, 24, 13-23. doi:10.1016/S0160-2896(97)90011-8

Gould, S. J. (1981). The mismeasure of man. New York, NY: W. W. Norton.

Gould, S. J. (1996). The mismeasure of man: Revised and expanded. New York, NY: W. W. Norton.

Grodin, M. A., Miller, E. L., \& Kelly, J. I. (2018). The Nazi physicians as leaders in eugenics and "euthanasia": Lessons for today. American Journal of Public Health, 108, 53-57. doi:10.2105/ajph.2017.304120

Hall, G. S. (1893). The contents of children's minds on entering school. New York, NY: E. L. Kellogg \& Co.

Henry, T. S. (Ed.). (1920). Classroom problems in the education of gifted children. The nineteeth yearbook of the National Society for the Study of Education (Pt. II). Chicago, IL: University of Chicago Press.

Hollingworth, H. L. (1990). Leta Stetter Hollingworth: A biography. Bolton, MA: Anker Publishing. 
Hollingworth, L. S. (1922). Subsequent history of E-; Five years after the initial report. Journal of Applied Psychology, 6, 205-210.

Hollingworth, L. S. (1924a). Provisions for intellectually superior children. In M. V. O’Shea (Ed.), The child: His name and needs (pp. 277-299). New York, NY: The Children Foundation.

Hollingworth, L. S. (1924b). An introduction to biography for young children who test above 150 IQ. Teachers College Record, 26, 277-287.

Hollingworth, L. S. (1926). Gifted children: Their nature and nurture. New York, NY: Macmillan.

Hollingworth, L. S. (1929). The production of gifted children from the parental point of view. Eugenics, 2, 3-7.

Hollingworth, L. S. (1936a). The Terman classes at Public School 500. Journal of Educational Sociology, 10, 86-90.

Hollingworth, L. S. (1936b). The founding of Public School 500: Speyer School. Teachers College Record, 38, 119-128.

Hollingworth, L. S. (1938). An enrichment curriculum for rapid learners at Public School 500: Speyer School. Teachers College Record, 39, 296-306.

Hollingworth, L. S. (1939). What we know about early selection and training of leaders. Teachers College Record, 40, 575-592.

Hollingworth, L. S. (1942). Children above 180IQ. Yonkers, NY: World Book Company.

Jensen, A. R. (1998). The g factor: The science of mental ability. Westport, CT: Praeger.

Jolly, J. L. (2006). Curriculum for gifted students: Lulu Stedman's contributions. Gifted Child Today, 29(1), 49-53. doi.org/10.4219/gct-2006-188 
Jolly, J. L. (2008). A paradoxical point of view: Lewis M. Terman. Gifted Child Today, 31(2), 36-37.

Jolly, J. L. (2007). Guy M. Whipple. Gifted Child Today, 30(1), 55-57. doi.org/10.4219/gct$2007-21$

Jolly, J. L. (2018). A history of American gifted education. New York, NY: Routledge.

Jolly, J. L., \& Kettler, T. (2008). Gifted education research 1994-2003: A disconnect between priorities and practice. Journal for the Education of the Gifted, 31, 427-446.

Kevles, D. J. (1995). In the name of eugenics: Genetics and the uses of human heredity. Cambridge, MA: Harvard University Press.

Kohlman, M. J. (2012). Evangelizing eugenics: A brief historiography of popular and formal American eugenics education (1908-1948). Alberta Journal of Educational Research, 58, 657-690.

Labree, D. F. (2005). Progressivism, schools, and schools of education: An American romance. Paedagogica Historica, 41, 275-288.

Lagemann, E. C. (2000). An elusive science: The troubling science of education research. Chicago, IL: The University of Chicago Press.

Leonard, T. C. (2005). Eugenics and economics in the progressive ear. Journal of Economic Perspectives, 19, 207-224.

Lubke, G. H., Dolan, C. V., Kelderman, H., \& Mellenbergh, G. J. (2003). On the relationship between sources of within- and between-group differences and measurement invariance in the common factor model. Intelligence, 31, 543-566. doi:10.1016/S01602896(03)00051-5 
MacKenzie, D. (1976). Eugenics in Britain. Social Studies of Science, 6, 499-532. doi:10.1177/030631277600600310

Martin, P. L., \& Duigan, P. (2003). Making and remaking America: Immigration into the United States. Retrieved from www.hoover.org/sites/default/files/uploads/documents/he_25.pdf Mayer, G. (2013). Child labor in America: History, policy, and legislative issues. Washington, DC: Congressional Research Service. Retrieved from http://fas.org/sgp/crs/misc/RL31501.pdf

McBee, M. T., \& Makel, M. C. (2019). The quantitative implications of definitions of giftedness. AERA Open, 5(1). doi:10.1177/2332858419831007

McBee, M. T., McCoach, D. B., Peters, S. J., \& Matthews, M. S. (2012). The case for a schism. Gifted Child Quarterly, 56, 210-214. doi:10.1177/0016986212456075

Minton, H. L. (2000). Terman, Lewis Madison. In A. E. Kazdin (Ed.), Encyclopedia of psychology (Vol. 8, pp. 37-39). Washington, DC: American Psychological Association.

Morelock, M. J. (1992). Giftedness: The view from within. Understanding Our Gifted, 4(3), 1115.

Morgan, P. L., Farkas, G., Hillemeier, M. M., \& Maczuga, S. (2016). Science achievement gaps begin very early, persist, and are largely explained by modifiable factors. Educational Researcher, 45, 18-35. doi:10.3102/0013189x 16633182

Naglieri, J. A. (2007). Traditional IQ: 100 years of misconception and its relationship to minority representation in gifted programs. In J. VanTassel-Baska (Ed.), Alternative assessments with gifted and talented students (pp. 67-88). Waco, TX: Prufrock Press. 
National Association for Gifted Children. (2013). State definitions of giftedness. Retrieved from http://www.nagc.org/sites/default/files/Advocacy/State\%20definitions\%20\%288-113\%29.pdf

NCES (National Center for Education Statistics). (1993). 120 years of American education: A statistical portrait. Washington, DC: U.S. Department of Education.

Nisbett, R. E., Aronson, J., Blair, C., Dickens, W., Flynn, J., Halpern, D. F., \& Turkheimer, E. (2012). Intelligence: New findings and theoretical developments. American Psychologist, 67, 130-159. doi:10.1037/a0026699

Norton, B. J. (1978). Karl Pearson and statistics: The social origins of scientific innovation. Social Studies of Science, 8, 3-34. doi:10.1177/030631277800800101

Collaboration, O. S. (2015). Estimating the reproducibility of psychological science. Science, 349(6251), aac4716-4711-aac4716-4719. doi:10.1126/science.aac4716

Pearson, K. (1896). Mathematical contributions to the theory of evolution. III. Regression, heredity, and panmixia. Philosophical Transactions of the Royal Society of London. Series A, Containing Papers of a Mathematical or Physical Character, 187, 253-318. doi:10.2307/90707

Peters, S. J., Gentry, M., Whiting, G. W., \& McBee, M. T. (2019). Who gets served in gifted education? Demographic representation and a call for action. Gifted Child Quarterly. [online first] doi $\underline{10.1177 / 0016986219833738}$

Renzulli, J. S. (1978). What makes giftedness? Reexamining a definition. Phi Delta Kappan, 60, 180-184, 261. doi:10.1177/003172171109200821

Richardson, J. G. (1980). Variation in the date of enactment of compulsory school attendance laws: An empirical inquiry. Sociology in Education, 53, 153-163. 
Ritchie, S. J. (2013). Book review: Giftedness 101, L.K. Silverman. Intelligence, 41, 275-276. doi:10.1016/j.intell.2013.04.002

Robinson, N. M. (2006). A report card on the state of research in the field of gifted education. Gifted Child Quarterly, 50, 342-345. doi:10.1177/001698620605000407

Robinson, N. M., Zigler, E., \& Gallagher, J. J. (2000). Two tails of the normal curve: Similarities and differences in the study of mental retardation and giftedness. American Psychologist, 55, 1413-1424. doi:10.1037/0003-066X.55.12.1413

Root, W. T. (1921). The socio-psychological study of fifty-three supernormal children. Psychological Monographs, 29(4), i-85.

Rudnitski, R. A. (1996). Leta Stetter Hollingworth and the Speyer School, 1934-1940: History roots of the contradictions in progressive education for gifted children. Education and Culture, 13, 1-6.

Selden, S. (1999). Inheriting shame: The story of eugenics and racism in America. New York, NY: Teachers College Press.

Selden, S. (2000). Eugencis and the social construction of merit, race and disability. Journal of Curriculum Studies, 32, 235-252.

Selden, S. (2005). Transforming better babies into fitter families: Archival resources and the history of American Eugenics Movement, 1908-1930. Proceedings of the American Philosophical Society, 149, 199-225.

Skidmore, S. T., \& Thompson, B. (2010). Statistical techniques used in published articles: A historical review of reviews. Educational and Psychological Measurement, 70, 777-795. doi: $10.1177 / 0013164410379320$ 
Snyderman, M., \& Herrnstein, R. J. (1983). Intelligence tests and the Immigration Act of 1924. American Psychologist, 38, 986-995. doi:10.1037/0003-066x.38.9.986

Stedman, L. M. (1924). Education of gifted children. Yonker-on-Hudson, NY: World Book Company.

Stepan, N. L. (1991). The hour of eugenics: Race, gender, and nation in Latin America. Ithaca, NY: Cornell University Press.

Stern, A. M. (2005). Sterilized in the name of public health. American Journal of Public Health, 95, 1128-1138. doi:10 2105/ajph.2004.041608

Stigler, S. M. (1986). The history of statistics: The measurement of uncertainty before 1900. Cambridge, MA: Harvard University Press.

Stoskopf, A. (2002). Echoes of a forgotten past: Eugenics, testing, and educational reform. Educational Forum, 66, 126-133.

Subotnik, R. F., Olszewski-Kubilius, P., \& Worrell, F. C. (2011). Rethinking giftedness and gifted education: A proposed direction forward based on psychological science. Psychological Science in the Public Interest, 12, 3-54.

Terman, L. M. (1916). The measurement of intelligence: An explanation of and a complete guide for the use of the Stanford revision and extension of the Binet-Simon Intelligence Scale. New York, NY: Houghton Mifflin.

Terman, L. M. (1922). A new approach to the study of genius. Psychological Review, 29, 310318. doi:10.1037/h0071072

Terman, L. M. (1925). Genetic studies of genius: Volume I. Palo Alto, CA: Stanford University Press. 
Terman, L. M. (1930). Autobiography of Lewis M. Terman. In C. Murchison (Ed.), History of psychology in autobiography (Vol. 2, pp. 297-331). Worcester, MA: Clark University Press.

Trotman Scott, M. F., Ford, D. Y., \& Davis, J. L. (2019). The issue of the 'UN' special issuePoints of reflection. Retrieved from https://www.nagc.org/issue-'un'-special-issue-pointsreflection

Tyack, D. (1976). Ways of seeing: An essay on the history of compulsory schooling. Havard Educational Review, 46, 355-389.

U.S. Citizenship and Immigration Service. (2012). Overview of INS history. Retrieved from www.uscis.gov/sites/default/files/USCIS/History\%20and\%20Genealogy/Our\%20History /INS\%20History/INSHistory.pdf

Vockell, E. L., \& Conard, F. (1992). Sources of information in gifted education literature. Gifted Child Quarterly, 36, 17-18. doi:10.1177/001698629203600104

Warne, R. T. (2016). Five reasons to put the $g$ back into giftedness: An argument for applying the Cattell-Horn-Carroll theory of intelligence to gifted education research and practice. Gifted Child Quarterly, 60, 3-15. doi:10.1177/0016986215605360

Warne, R. T. (2018). Statistics for the social sciences: A general linear model approach. New York, NY: Cambridge University Press.

Warne, R. T. (2019). An evaluation (and vindication?) of Lewis Terman: What the father of gifted education can teach the 21st century. Gifted Child Quarterly, 63, 3-21. doi: $10.1177 / 0016986218799433$ 
Warne, R. T., Anderson, B., \& Johnson, A. O. (2013). The impact of race and ethnicity on the identification process for giftedness in Utah. Journal for the Education of the Gifted, 36, 487-508. doi:10.1177/0162353213506065

Warne, R. T., Burton, J. Z., Gibbons, A., \& Melendez, D. 2019). Stephen Jay Gould's analysis of the Army Beta test in The Mismeasure of Man: Distortions and misconceptions regarding a pioneering mental test. Journal of Intelligence, 7(1), 6.

doi:10.3390/jintelligence7010006

Warne, R. T., Lazo, M., Ramos, T., \& Ritter, N. (2012). Statistical methods used in gifted education journals, 2006-2010. Gifted Child Quarterly, 56, 134-149. doi:10.1177/0016986212444122

Whipple, G. M. (1910). Manual of mental and physical tests. Baltimore, MD: Warwick \& York. Whipple, G. M. (1919). Classes for gifted children. Bloomington, IL: Public School Publishing Company.

Whipple, G. M. (1922). Educational determinism: A discussion of Professor Bagley's address at Chicago. School and Society, 15, 599-602.

Wigtil, C. J., \& White, W. L. (2017). Children above 180 Stanford-Binet: A seventy-five year follow-up. Journal of Genius and Eminence, 2(1), 77-91. doi:10.8536/jge.2017.04.02.01.08

Wineburg, S. (2001). Historical thinking and other unnatural acts: Charting the future of teaching the past. Philadelphia, PA: Temple University Press.

Winker, D. L., \& Jolly, J. L. (2014). Lewis M. Terman: A misunderstood legacy. In A. Robinson \& J. L. Jolly (Eds.), A century of contributions to gifted education: Illuminating lives (pp. 64-78). New York, NY: Routledge. 
Wolf, T. H. (1973). Alfred Binet. Chicago, IL: The University of Chicago Press.

Young, K. (1924). The history of mental testing. The Pedagogical Seminary, 31, 1-48. doi:10.1080/08919402.1924.10532922 